\title{
Respon Imun Non-spesifik Ikan Gurami (Osphronemus gouramy) yang Diberi Fucoidan dari Ekstrak Rumput Laut Cokelat Padina sp.
}

\author{
Non-specific Response of Gouramy Fish (Osphronemus gouramy) Given \\ Fucoidan From Brown Seaweed Extract Padina sp.
}

\author{
Cahyono Purbomartono ${ }^{1}$, Dini Siswani Mulia ${ }^{2}$, Danang Priyambodo ${ }^{2}$ \\ ${ }^{1,2}$ Program Studi Pendidikan Biologi, Universitas Muhammadiyah Purwokerto \\ 1'cahyonopurbomartono@gmail.com
}

\begin{abstract}
ABSTRAK
Fucoidan merupakan senyawa polisakarida sulfat yang diekstrak dari rumput laut cokelat Padina sp. Fucoidan diketahui mempunyai beberapa bioaktivitas, salah satunya sebagai imunostimulan. Ikan gurami (Osphronemus gouramy) ukuran \pm 100 gr diberi perlakuan fucoidan yang dicampur kedalam pakan dengan dosis $0,2 \mathrm{gr} \mathrm{kg}^{-1}$ pakan (P1), 0,4 $\mathrm{gr} \mathrm{kg}^{-1}$ pakan (P2) , 0,6 gr kg ${ }^{-1}$ pakan (P3) serta kontrol (Po) masing-masing dengan 3 kali ulangan. Hasil penelitian menunjukkan, fucoidan dari ekstrak rumput laut cokelat Padina sp. secara signifikan dapat meningkatkan respon imun non-spesifik terhadap persentase hematokrit, leukokrit dan superoksida anion pada ikan gurami. Perlakuan P3 $\left(0,6 \mathrm{gr} \mathrm{kg}^{-1}\right)$ merupakan dosis optimum yang dapat meningkatkan respon imun non-spesifik ikan, menunjukkan fucoidan dapat digunakan dalam budidaya ikan gurami.
\end{abstract}

Kata kunci: fucoidan, Padina sp., ikan gurami, imun non-spesifik

\begin{abstract}
Fucoidan is a polysaccharide sulfate compound extracted from brown seaweed Padina sp. Fucoidan is known to have some bioactivity, one of which is immunostimulant. Gouramy (Osphronemus gouramy) size $\pm 100 \mathrm{gr}$ was treated with fucoidan mixed into feed at a dose of $0.2 \mathrm{gr} \mathrm{kg}^{-1}$ of feed (P1), $0.4 \mathrm{gr} \mathrm{kg}^{-1}$ of feed (P2), $0.6 \mathrm{gr} \mathrm{kg}^{-1}$ of feed (P3) and control $(\mathrm{Po})$ with 3 replications. The results showed, fucoidan from brown seaweed extract Padina sp. can significantly increase the non-specific immune response to the percentage of hematocrit, leukocrit and superoxide anion in gouramy. P3 treatment (0.6 $\mathrm{gr}_{\mathrm{kg}}^{-1}$ ) is the optimum dose that can improve the non-specific immune response of gouramy, proving that fucoidan can be used in the cultivation of gouramy.
\end{abstract}

Keywords: fucoidan, Padina sp., gouramy fish, non-spesific immune

\section{PENDAHULUAN}

Permintaan produk perikanan semakin meningkat seiring dengan meningkatnya jumlah penduduk. Produk perikanan berupa daging ikan segar maupun yang sudah di fillet mempunyai kandungan protein yang dibutuhkan oleh manusia. Ikan gurami merupakan salah satu jenis ikan air tawar yang diminati oleh masyarakat karena rasa dagingnya enak dan tersedia di pasaran. Sementara petani melakukan budidaya ikan gurami karena harganya cukup tinggi sekitar 60 ribu rupiah per kilogram (Irmawati, 2013). Dalam rangka memenuhi kebutuhan konsumen serta permintaan pasar, petani melakukan budidaya ikan gurami secaa intensif, namun demikian terdapat beberapa kendala.

(Respon Imun Non-spesifik ............ Cahyono Purbomartono, Dini Siswani Mulia, Danang Priyambodo) 
Beberapa kendala yang dihadapi oleh pembudidaya seperti harga pakan yang relatif tinggi, kualitas air serta penyakit. Harga pakan yang tinggi biasanya disiasati dengan memberikan pakan dari tanaman tallas yang ditanam di galengan. Kualitas air dapat diperbaiki melalui resirkulasi air dengan melewatkan pada tandon air yang sudah difilter. Kendala penyakit merupakan salah satu kendala yang timbulnya belum dapat diprediksi sehingga bisa menimbulkan infeksi, wabah dan kematian ikan. Salah satu penyakit yang sering menyerang ikan; termasuk ikan gurami, adalah penyakit bercak merah atau Motile Aeromonas Septicemia (MAS). Penyakit MAS disebabkan oleh bakteri Aeromonas hydrophila, termasuk dalam bakteri patogen gram negatif dan bersifat motil. Ikan yang terserang penyakit mempunyai karakteristik warna ikan menjadi lebih gelap atau pucat, diam dan menyendiri, gerakan lambat, terdapat bercak-bercak merah pada tubuh, sirip geripis, perdarahan pada organ dalam, eksudat (cairan radang) didalam rongga perut serta ginjal mengalami pembengkakan yang disertai hemoraghi (Prajitno, 2005). Infeksi A. hydrophila pada umumnya menyebabkan kematian, dalam waktu 1-2 minggu bisa mencapai 80\% - 100\% (Cipriano, 2001).

Timbulnya penyakit disebabkan adanya interaksi yang tidak serasi antara ikan, patogen dan lingkungan, sehingga menyebabkan stres pada ikan. Stres pada ikan menyebabkan sistim pertahanan tubuh melemah sehingga penyakit mudah menyerang. Selama ini penyakit bakteri diobati menggunakan antibiotika, namun apabila tidak tepat dapat menimbulkan resistensi, pencemaran lingkungan serta merugikan konsumen karena adanya residu dalah tubuh ikan. Untuk menanggulangi secara aman, diperlukan tindakanalternatif diantaranya dengan upaya pencegahan (preventif). Pencegahan dapat dilakukan dengan vaksinasi atau imunostimulan, namun vaksinasi relatif mahal dan hanya untuk penyakit tertentu saja. Penggunaan imunostimulan aman digunakan, bersifat umum untuk semua antigen atau mikroorganisme serta ramah lingkungan (Alifuddin, 2002).

Imunostimulan dapat berasal dari tanaman (herbal) maupun sintetik. Rumput laut merupakan salah satu imunostimulan herbal seperti rumput laut merah serta cokelat. Rumput laut cokelat memiliki substansi zak bioaktif seperti alginat dan fucoidan yang dapat berfungsi sebagai imunostimulan yang mampu meningkatkan sistem ketahanan udang vaname (L. vannamei) dan bersifat sebagai antibakteri (Cheng et al., 2004).

Padina sp. adalah salah satu rumput laut cokelat yang didalam dinding selnya mengandung fucoidan. Fucoidan merupakan suatu polisakarida, disebut phycocolloid, mengandung serat yang mudah larut dalam air. Serat fucoidan membentuk kisi-kisi seperti jala yang mampu mengikat kuat molekul air dan menahan zat terlarut air dengan baik (Prasetya, 2009). Fucoidan diketahui dapat meningkatkan sistem kekebalan tubuh pada ikan Epinephelus brneus, juvenil Epinephelus fuscoguttatus dan abalon (Haliotisdiversicolor supertexta) (Harikrishnan et al., 2011). Fucoidan yang dicampur dalam pakan untuk ikan gurami (Osphronemus gouramy) pada penelitian ini bertujuan untuk mengetahui pengaruhnya terhadap ketahanan tubuh non-spesifik serta dosis optimal yang diperoleh pada ikan gurami.

\section{METODE}

Rumput laut diperoleh dari perairan pantai Menganti, Kebumen, Jawa Tengah. Identifikasi rumput laut dilakukan secara morfologi berdasarkan database http://www.algaebase.org. Penelitian menggunakan ikan gurami dengan berat \pm 100 gr.

Metode penelitian dilakukan secara eksperimental laboratorium menggunakan rancangan acak lengkap. Penelitian dilakukan selama 12 hari dengan 3 perlakuan dan 1 kontrol, masing-masing dengan 3 kali ulangan individu. Dosis perlakuan $(\mathrm{P})$ yang digunakan P1 0,2 $\mathrm{g} \mathrm{kg}^{-1}$ pakan, P2 $0,4 \mathrm{~g} \mathrm{~kg}^{-1}$ pakan, P3 $0,6 \mathrm{~g} \mathrm{~kg}^{-1}$ pakan dan kontrol. Parameter imun non-spesifik ikan yang diamati meliputi persentase hematokrit, leukokrit 
dan SOA menggunakan sampel darah serta data pendukung kualitas air meliputi suhu, $\mathrm{pH}$ dan kelarutan oksigen. Pengambilan sampel darah dilakukan pada hari ke-0 (sebelum perlakuan), dan hari ke 4, 8 dan 12 setelah perlakuan. Ekstraksi rumput laut dilakukan dengan menggunakan metode asam.

\section{A. Ekstraksi}

Rumput laut dikering-anginkan selama 24 jam dalam laboratorium tanpa penyinaran matahari langsung. Rumput laut yang telah kering-angin dipotong-potong ( \pm $0,5 \mathrm{~cm}$ ), dihaluskan dengan blender dan selanjutnya direndam dalam larutan $\mathrm{HCl} 0,1 \mathrm{~N}$ selama \pm 24 jam. Maserasi dilakukan selama 24 jam sambil diaduk setiap 1 jam, kemudian disaring untuk diambil filtrat dan ampasnya (retentate). Retentate dimaserasi kembali dengan larutan $\mathrm{HCl} 0,2 \mathrm{~N}$ dan dipanaskan pada suhu $60^{\circ} \mathrm{C}$ selama $2 \mathrm{jam}$, kemudian disaring kembali untuk mendapatkan filtrat sedangkan ampasnya dibuang. Filtrat I dan ke II disatukan kemudian disaring menggunakan kertas saring dan kertas whatman 41. Filtrat dievaporasi dengan menggunakan rotary evaporator dengan suhu $60^{\circ} \mathrm{C}$. Setelah evaporasi selesai, $\mathrm{pH}$ filtrat dinetralkan menggunakan $\mathrm{NaOH}$, kemudian dipresipitasi menggunakan alkohol dingin $96 \%$ sebanyak 3 kali volume filtrat, selanjutnya disentrifuge dengan kecepatan $3000 \mathrm{rpm}$ selama 10 menit. Supernatan dibuang dan pellet dilarutkan dalam akuades, kemudian ditambahkan $\mathrm{HCl}$ hingga $\mathrm{pH} 2$ dan selanjutnya dipresipitasi menggunakan $\mathrm{CaCl}_{2}$ konsentrasi $2 \mathrm{M}$. Larutan selanjutnya disentrifuge dengan kecepatan $3000 \mathrm{rpm}$ selama 15 menit. Endapan yang terbentuk merupakan alginat, sedangkan supernatan merupakan fucoidan. Selanjutnya supernatan disentrifuge dengan kecepatan $3000 \mathrm{rpm}$ selama 10 menit dan endapan yang terbentuk merupakan fucoidan.

\section{B. Pembuatan Pakan}

Ekstrak rumput laut cokelat ditimbang sesuai dosis perlakuan kemudian dicampur progol $0,1 \%$ sebagai perekat, dikocok hingga homogen, kemudian disemprotkan ke pakan pelet dan dikering-anginkan. Setelah kering, pakan dapat disimpan dalam suhu dingin apabila belum langsung digunakan. Pakan diberikan dengan dosis 3\%/berat biomas/hari sebanyak 2 kali, pada pagi dan sore hari.

\section{Pemeliharaan}

Ikan gurami didistribusikan ke dalam 4 ember berukuran 50x50x60 $\mathrm{cm}^{3}$ yang ditutup dengan kain kasa. Selama pemeliharaan dilakukan pergantian air dan siphon selama 2 hari sekali. Ikan diaklimatisasi selama 7 hari dengan diberi pakan pelet sebanyak $2 x$, pada pagi dan sore hari. Penelitian dimulai setelah selesai aklimatisasi dan ikan sudah stabil.

\section{HASIL DAN PEMBAHASAN}

Parameter yang diukur pada penelitian ini meliputi persentase hematokrit, leukokrit, dan kadar superoksida anion (SOA) serta data pendukung berupa kualitas air.

\section{A. Persentase hematokrit}

Kadar hematokrit menunjukkan persentase sel darah merah dalam sirkulasi darah. Hasil perhitungan rata-rata hematokrit ikan gurami (Osphronemus goramy) dengan menggunakan ekstrak fucoidan dari rumput laut cokelat (Padina sp) yang diberikan selama 12 hari pada perlakuan P0, P1, P2, dan P3 dapat dilihat pada Tabel 1.

(Respon Imun Non-spesifik ........... Cahyono Purbomartono, Dini Siswani Mulia, Danang 
Tabel 1. Persentase hematokrit (\%) ikan gurami pada hari ke $0,4,8$ dan 12 setelah pemberian pakan yang mengandung fucoidan Padina sp.

\begin{tabular}{ccccc}
\hline \multirow{2}{*}{ Perlakuan } & \multicolumn{4}{c}{ Lama Penelitian hari ke- } \\
\cline { 2 - 5 } & $\mathbf{0}$ & $\mathbf{4}$ & $\mathbf{8}$ & $\mathbf{1 2}$ \\
\hline P0 & $43,33 \pm 1,92^{\mathrm{a}}$ & $45,82 \pm 2,88^{\mathrm{a}}$ & $45,83 \pm 3,19^{\mathrm{a}}$ & $44,99 \pm 2,72^{\mathrm{a}}$ \\
P1 & $46,24 \pm 3,69^{\mathrm{a}}$ & $48,74 \pm 2,09^{\mathrm{a}}$ & $51,66 \pm 2,35^{\mathrm{ab}}$ & $52,49 \pm 4,41^{\mathrm{ab}}$ \\
P2 & $47,91 \pm 2,09^{\mathrm{a}}$ & $50,83 \pm 7,98^{\mathrm{a}}$ & $49,16 \pm 5,17^{\mathrm{ab}}$ & $50,41 \pm 1,59^{\mathrm{ab}}$ \\
P3 & $47,50 \pm 5,00^{\mathrm{a}}$ & $50,41 \pm 4,90^{\mathrm{b}}$ & $48,75 \pm 2,50^{\mathrm{b}}$ & $53,33 \pm 7,81^{\mathrm{b}}$ \\
\hline
\end{tabular}

Keterangan: Nilai rerata yang diikuti huruf superscript yang berbeda menunjukkan berbeda nyata pada uji DMRT dengan taraf uji 5\%, P0: kontrol (pakan tanpa ekstrak rumput laut), P1: 0,2 gr ekstrak kg-1 pakan, P2: 0,4 gr ekstrak kg-1 pakan, P3: 0,6 gr ekstrakkg ${ }^{-1}$ pakan.

Berdasarkan hasil analisis statistik sidik ragam (ANOVA) dengan uji lanjut Duncan pada taraf kepercayaan 95\% $(p<0,05)$, menunjukkan bahwa pemberian fucoidan pada hari ke-4, 8 dan 12, perlakuan P3 (0,6 gr) berbeda nyata terhadap P0 (kontrol). Kadar

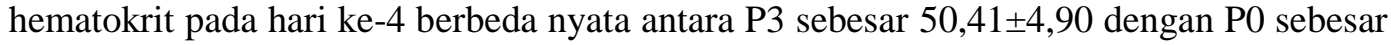
$45,82 \pm 2,88$. Pada hari ke-8 P3 sebesar 48,75 $\pm 2,50$ berbeda nyata dengan P0 45,83 $\pm 3,19$

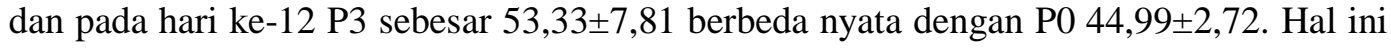
menunjukan bahwa penambahan fucoidan dari rumput laut cokelat (Padina sp.) pada P3 efektif untuk meningkatkan persentase hematokrit pada ikan gurami. Pendapat yang berbeda disampaikan oleh Anderson (1992), bahwa nilai hematokrit yang rendah pada ikan dapat mengindikasikan adanya kontaminasi, kurang nafsu makan, kadar protein yang rendah pada ransum pakan, adanya defisiensi vitamin serta kemungkinan infeksi penyakit.

Persentase atau kadar hematokrit pada penelitian ini masih berada pada kisaran normal antara 43,33\% - 53,33\%, menunjukan bahwa ikan gurami dalam kondisi sehat. Snieszko et al. (1960) dalam Marthen (2005) menyatakan, nilai hematokrit darah ikan berkisar antara 5-60 \%. Menurut Gallaugher et al. (1995), bahwa nilai hematokrit yang lebih kecil dari 22\% menunjukkan ikan mengalami anemia. Hal ini didukung oleh pendapat Randal (1970) dalam Marifatun (2015) yang menyatakan apabila nilai hematokrit dibawah 22\% menunjukkan ikan mengalami anemia serta kemungkinan mengalami infeksi penyakit bakteri. Wedemeyer dan Yasutake (1977) berpendapat bahwa ikan dikatakan stress apabila kadar hematokritnya dalam darah lebih besar dari $60 \%$. Faktor yang menyebabkan kadar hematokrit pada ikan berbeda-beda tergantung pada umur, jenis kelamin, masa pemijahan, ukuran tubuh dan nutrisi (Kuswandi, 2006).

Rumput laut mempunyai kandungan bahan-bahan organik seperti polisakarida, hormon, vitamin, mineral, dan juga senyawa bioaktif yang berperan sebagai immunostimulan pada ikan. Pada penelitian ini membuktikan bahwa fucoidan dari rumput laut cokelat (Padina sp.) mengandung bahan immunostimulan yang dapat meningkatkan persentase hematokrit pada ikan gurami.

\section{B. Persentase leukokrit}

Hasil pengamatan persentase leukokrit ikan gurami (Osphronemus goramy) dengan penambahan ekstrak rumput laut cokelat (Padina sp.) yang diberikan selama 12 hari pada perlakuan P0, P1, P2 dan P3 tersaji pada Tabel 2. 
Tabel 2. Persentase leukokrit (\%) gurami pada hari ke 0, 4, 8 dan 12 setelah pemberian pakan dengan fucoidan Padina sp. dengan berbagai dosis.

\begin{tabular}{ccccc}
\hline \multirow{2}{*}{ Perlakuan } & \multicolumn{4}{c}{ Lama penelitian hari ke- } \\
\cline { 2 - 5 } & $\mathbf{0}$ & $\mathbf{4}$ & $\mathbf{8}$ & $\mathbf{1 2}$ \\
\hline P0 & $3,72 \pm 1,62^{\mathrm{a}}$ & $2,87 \pm 1,62^{\mathrm{a}}$ & $2,02 \pm 0,85^{\mathrm{a}}$ & $2,87 \pm 1,62^{\mathrm{a}}$ \\
P1 & $3,72 \pm 1,62^{\mathrm{a}}$ & $2,45 \pm 0,98^{\mathrm{a}}$ & $3,72 \pm 0,85^{\mathrm{ab}}$ & $3,72 \pm 1,62^{\mathrm{a}}$ \\
P2 & $5,4 \pm 0,8^{\mathrm{ab}}$ & $5,37 \pm 1,57^{\mathrm{b}}$ & $5,8 \pm 2,14^{\mathrm{bc}}$ & $5,37 \pm 1,57^{\mathrm{a}}$ \\
P3 & $7,02 \pm 0,85^{\mathrm{b}}$ & $6,22 \pm 1,57^{\mathrm{b}}$ & $6,22 \pm 1,57^{\mathrm{b}}$ & $4,95 \pm 1,9^{\mathrm{a}}$ \\
\hline
\end{tabular}

Keterangan: Nilai rerata yang diikuti huruf superscript yang berbeda menunjukkan berbeda nyata pada uji DMRT dengan taraf uji 5\%, P0: kontrol (pakan tanpa ekstrak rumput laut), P1: 0,2 gr ekstrak $\mathrm{kg}^{-1}$ pakan, P2: 0,4 gr ekstrak $\mathrm{kg}^{-1}$ pakan $\mathrm{g}, \mathrm{P} 3:$ 0,6 gr ekstrak $\mathrm{kg}^{-1}$ pakan.

Berdasarkan hasil analisis statistik sidik ragam (ANOVA) dengan uji lanjut Duncan pada taraf kepercayaan 95\% $(p<0,05)$, menunjukkan bahwa pemberian fucoidan dari rumput laut cokelat (Padina sp.) pada hari ke-4 dan ke-8 pada perlakuan P2 dan P3 menunjukan pengaruh berbeda nyata terhadap P0. Pada hari ke-4 yaitu perlakuan P2 sebesar 5,37 $\pm 1,57$ dan P3 $(6,22 \pm 1,57)$ berbeda nyata dengan P0 $(2,87 \pm 1,62)$. Sedangkan pada hari ke-8 perlakuan P2 sebesar 5,8 $\pm 2,14$ dan P3 $(6,22 \pm 1,57)$ menunjukan pengaruh berbeda nyata terhadap P0 $(2,02 \pm 0,85)$. Persentase rerata kadar leukokrit pada ikan uji yang tertinggi terdapat pada perlakuan P3 sebesar 7,02 diikuti perlakuan P2 sebesar 5,8, dan P1 sebesar 3,72 serta yang terendah pada perlakuan P0 sebesar 2,02.

Ekstrak Padina sp. dapat meningkatkan kadar leukokrit ikan karena mempunyai kandungan utama berupa polisakarida agar-agar yang biasanya disebut agarofit dan karaginofit (polisakarida karagin). Selain itu, bahan rumput laut yang mempunyai kemampuan menstimulasi adalah adanya polisakarida bersulfat, diantaranya sulfated galactan (agaropektin). Kelompok sulfat dalam rumput laut cokelat berfungsi sebagai immunomodulatory activities pada mamalia (Castro et al; dalam Marifatun, (2015). Pada penelitian yang dilkukan Ridlo (2009), menyatakan bahwa suplementasi ekstrak rumput laut Dictyota sp., Gracilaria sp., Padina sp. dan Sargassum sp. mampu meningkatkan jumlah total hemosit dan aktivitas fagositosis udang L. vannamei. Pada penelitian Puspita (2010) juga menyatakan bahwa penambahan ekstrak Padina sp. dapat merangsang aktivitas sel dan meningkatkan jumlah sel darah putih dalam membinasahkan infeksi patogen. Leukokrit secara umum memberikan respon terhadap semua antigen maupun mikroorganisme, kemudian dipresentasikan kedapa sel $\mathrm{T}$ yang bersifat seluler (Cell Mediated Immunity; CMI). Meningkatnya kadar leukrokrit merupakan petunjuk adanya respon sel darah putih terhadap imunostimulan maupun turunannya yang berupa antigen maupun mikroorganisme patogen. Beberapa penelitian yang lain menunjukan bahwa rumput laut dapat menstimulasi sistem imun non-spesifik pada ikan serta meningkatkan resistensinya terhadap penyakit. Bahan utama imunostimulan yang dihasilkan oleh ekstrak rumput laut cokelat (Padina sp.) berupa senyawa polisakarida, merupakan komponen bioaktif yang mampu meningkatkan sistem imun non-spesifik pada ikan serta proteksi terhadap infeksi (Castro et al., (2006) dalam Jasmanindar (2009).

Berdasarkan hasil penelitian menunjukkan, penambahan fucoidan dari ekstrak rumput laut cokelat (Padina sp.) pada pakan mampu meningkatkan persentase leukokrit ikan gurami (Osphronemus goramy). Didukung hasil penelitian yang dilakukan oleh Marifatun (2015), bahwa pemberian ekstrak rumput laut merah (Gracilaria verrucosa) juga dapat meningkatkan kadar leukokrit ikan nila (Oreochrimis niloticus). Menurut Anderson dan Siwicki (1994), leukokrit yang rendah dapat disebabkan oleh infeksi kronis, kualitas nutrisi yang rendah, kekurangan vitamin serta adanya kontaminan.

(Respon Imun Non-spesifik ............ Cahyono Purbomartono, Dini Siswani Mulia, Danang 
Rendahnya leukokrit juga dapat disebabkan oleh infeksi awal dan stres. Persentase leukokrit dalam darah dapat dijadikan petunjuk status kesehatan ikan yang bersangkutan.

\section{Uji superoksida anion (SOA)}

Hasil pengamatan uji SOA setelah diberi pakan dengan penambahan ekstrak rumput laut coklat (Padina sp.) selama 12 hari penelitian dengan dosis yang berbeda disajikan pada Tabel 3 .

Berdasarkan hasil analisis statistik sidik ragam (ANOVA) dengan uji lanjut Duncan pada taraf kepercayaan 95\% ( $p<0,05)$, menunjukkan bahwa pemberian fucoidan dari rumput laut cokelat (Padina sp.) pada hari ke-8 dan hari ke-12 berbeda nyata terhadap P0 (kontrol). Hal ini menunjukkan bahwa fucoidan dari ekstrak Padina sp. mampu meningkatkan respon imun non-spesifik SOA pada ikan gurami. Fucoidan mempunyai kandungan polisakarida yang berfungsi sebagai imunostimulan dalam meningkatan imunitas ikan. Sumber lain membyktikan, pemberian imunostimulan dari ekstrak Aloevera mampu meningkatkan produksi SOA, membunuh mikroorganisme serta menekan mekanisme induksi apoptosis.

Leukosit baik monosit maupun neutrofil dalam darah cenderung meningkatkan konsumsi oksigen melalui proses oksidasi NADPH dan membentuk oksigen radikal dalam bentuk anion superoksida $\left(\mathrm{O}_{2^{-}}\right)$, hydroxyl radikal $(-\mathrm{OH})$, hydrogen peroksida $\left(\mathrm{H}_{2} \mathrm{O}_{2}\right)$, dan lipid peroksida $(\mathrm{ROOH})$. Senyawa tersebut merupakan antibakteri potensial yang akan menjaga tubuh ikan dari infeksi patogen melalui beberapa mekanisme, diantaranya letupan respirasi (respiratory burst). Respiratory burst merupakan pembentuk dasar sistem antibakteri yang ada pada tubuh ikan. Meningkatnya respiratory burst dapat dikorelasikan dengan peningkatan aktifitas sel fagositik (Rawling et al. 2012). Respiratory burst dapat meningkatkan konsumsi oksigen sehingga dapat mengakibatkan terbentuknya SOA dan proses ini dipercepat oleh NADPH-oksidase, multi komponen enzim yang telah terpasang pada permukaan bagian dalam dari membran plasma setelah terjadinya aktivasi untuk melakukan fagositik (Rieger, 2011).

Nilai Reactive Oxygen Species (ROS) yang terukur oleh indikator NBT dilepaskan oleh sel imun untuk merusak membran patogen yang menginfeksi ikan. Menurut Neumann et al. (2000a,b) dan Mathias et al. (2009), sel monosit dan neutrofil adalah sel yang berperan sebagai fagosit terhadap benda asing melalui membran reseptor. Saat peradangan dan terdapat luka pada jaringan, sitokin akan dilepaskan oleh sel fagosit sebagai sinyal inflamasi yang akan memicu proses kemotaksis jaringan dan penyembuhan luka.

Tabel 3. Kadar SOA ikan gurami pada hari ke $0,4,8$ dan 12 setelah pemberian pakan dengan fucoidan Padina sp. dengan berbagai dosis.

\begin{tabular}{ccccc}
\hline \multirow{2}{*}{ Perlakuan } & \multicolumn{4}{c}{ Lama penelitian hari ke- } \\
\cline { 2 - 5 } & $\mathbf{0}$ & $\mathbf{4}$ & $\mathbf{8}$ & $\mathbf{1 2}$ \\
\hline P0 & $0,29 \pm 0,05^{\mathrm{a}}$ & $0,33 \pm 0,09^{\mathrm{a}}$ & $0,31 \pm 0,10^{\mathrm{a}}$ & $0,38 \pm 0,03^{\mathrm{a}}$ \\
P1 & $0,34 \pm 0,06^{\mathrm{a}}$ & $0,37 \pm 0,05^{\mathrm{a}}$ & $0,48 \pm 0,05^{\mathrm{b}}$ & $0,46 \pm 0,07^{\mathrm{ab}}$ \\
P2 & $0,33 \pm 0,55^{\mathrm{a}}$ & $0,35 \pm 0,06^{\mathrm{a}}$ & $0,45 \pm 0,11^{\mathrm{b}}$ & $0,50 \pm 0,05^{\mathrm{b}}$ \\
P3 & $0,33 \pm 0,68^{\mathrm{a}}$ & $0,41 \pm 0,07^{\mathrm{a}}$ & $0,51 \pm 0,05^{\mathrm{b}}$ & $0,54 \pm 0,02^{\mathrm{b}}$
\end{tabular}

Keterangan: Nilai rerata yang diikuti huruf superscript yang berbeda menunjukkan berbeda nyata pada uji DMRT dengan taraf uji 5\%, P0: kontrol (pakan tanpa ekstrak

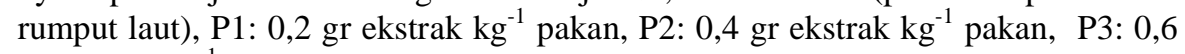
gr ekstrak $\mathrm{kg}^{-1}$ pakan.

(Respon Imun Non-spesifik ............ Cahyono Purbomartono, Dini Siswani Mulia, Danang 


\section{Kualitas air}

Air merupakan elemen yang sangat erat hubungannya dalam kegiatan akuakultur. Kualitas air yang baik dapat mempengaruhi komoditas perikanan yang sedang dibudidayakan. Parameter fisika dan kimia air yang berpengaruh terhadap kehidupan dan pertumbuhan ikan diantaranya suhu, $\mathrm{pH}$ dan oksigen terlarut (DO). Data parameter kualitas air selama penelitian disajikan pada Tabel 4.

Tabel 4. Rerata kualitas air selama penelitian

\begin{tabular}{cccc}
\hline \multirow{2}{*}{ Perlakuan } & \multicolumn{3}{c}{ Parameter kualitas Air } \\
\cline { 2 - 4 } & Suhu $\left({ }^{\circ} \mathbf{C}\right)$ & pH & DO \\
\hline P0 & $27,2-27,5$ & $7,1-7,3$ & $8,9-9,2$ \\
P1 & $26,3-27,4$ & $7,1-7,2$ & $9,1-9,3$ \\
P2 & $27,1-27,3$ & $6,9-7,0$ & $9,1-9,3$ \\
P3 & $27,1-27,4$ & $7,1-7,2$ & $9,0-9,2$ \\
\hline
\end{tabular}

Hasil pengukuran suhu air selama penelitian berkisar antara $26,3-27,5{ }^{\circ} \mathrm{C}$, derajat keasaman air $(\mathrm{pH})$ berkisar antara 6,9-7,3 dan DO berkisar antara 8,9-9,3 ppm.

\section{E. Suhu $\left({ }^{\circ} \mathrm{C}\right)$}

Suhu memiliki peran dalam mengendalikan kondisi ekosistem perairan. Suhu $\left({ }^{\circ} \mathrm{C}\right)$ pada semua perlakuan berkisar antara $26,3-27,5^{\circ} \mathrm{C}$, hal ini masih berada dalam batas toleransi ikan gurami. Suhu optimal habitat hidup gurami berkisar antara $24-28^{\circ} \mathrm{C}$ (Khairuman dan Amri, 2003). Peningkatan suhu mengakibatkan peningkatan kecepatan metabolisme serta respirasi organisme air dan selanjutnya menyebabkan peningkatan konsumsi oksigen. Suhu yang tinggi mengurangi tingkat kelarutan oksigen didalam air (Effendi, 2003). Sedangkan penurunan suhu hingga $21^{\circ} \mathrm{C}$ pada media dapat menurunkan metabolisme dan tingkat konsumsi oksigen.

\section{F. Derajat keasaman (pH)}

Pengaruh $\mathrm{pH}$ terhadap ikan bervariasi tergantung spesies, ukuran, suhu, konsentrasi karbondioksida dan kehadiran logam berat seperti Fe (Alabaster dan Lloyd, 1980). Leivestad dalam Boyd (1990) menyatakan bahwa jaringan insang menjadi sasaran utama untuk terkena stres asam. Menurut Khairuman dan Amri (2003) kisaran $\mathrm{pH}$ yang dapat ditoleransi untuk kehidupan ikan gurami adalah 5-9. Derajat keasaman $(\mathrm{pH})$ pada semua perlakuan berkisar antara 6,9-7,3, sehingga $\mathrm{pH}$ selama perlakuan masih dianggap memenuhi persyaratan dalam budidaya ikan gurami.

\section{G. Oksigen terlarut (DO)}

Oksigen terlarut adalah jumlah mg/l gas oksigen yang terlarut dalam air, kandungan $\mathrm{O}_{2}$ yang terlalu tinggi menyebabkan timbulnya gelembung-gelembung pada jaringan tubuh, sebaliknya penurunan kandungan $\mathrm{O}_{2}$ secara tiba-tiba dapat menyebabkan kematian. Menurut Taufik (1984) kadar oksigen optimum untuk pemeliharaan ikan pada kisaran 6,5 - 12,5 mg/l, sedangkan pada penelitian ini berkisar antara 8,9-9,3 ppm. Kisaran tersebut masih dalam kondisi optimum dalam pemeliharaan ikan.

\section{KESIMPULAN}

Suplementasi fucoidan dari ekstrak Padina sp. melalui pakan dapat meningkatkan secara signifikan respon imun non-spesifik persentase hematokrit, leukokrit dan kadar SOA ikan gurami. Dosis perlakuan P3 (0,6 gr kg ${ }^{-1}$ pakan) merupakan dosis optimum yang

(Respon Imun Non-spesifik ........... Cahyono Purbomartono, Dini Siswani Mulia, Danang 
dapat meningkatkan respon imun non-spesifik ikan gurami. Oleh karena itu, fucoidan dari ekstrak Padina sp. potensial digunakan sebagai imunostimulan pada budidaya ikan gurami.

\section{DAFTAR PUSTAKA}

Alabaster, J. S. and R. Lloyd, 1980. Water Quality Criteria for Freshwater Fish. Buttenvorths. 297 p.

Alifuddin, M., 1999. Peran Imunostimulan (Lipopolisakarida, Saccharomyces cere-visiae and Levamisol) terhadap Peningkatan Respons Imunitas Ikan Jambal Siam (Pangasius hypopthalmus). Tesis. Program Studi Ilmu Perairan. Program Pascasarjana IPB, Bogor. 50 hal.

Alifuddin, M. 2002. Imunostimulasi pada Hewan Akuatik. Jurnal Akuakultur Indonesia. 1(2): 87-92.

Anderson, D.P. \& A.K. Siwicki. 1994. Simplified assays for Measuring Non-specific Defense Mechanisms In Fish. Fish Health Section/American Fisheries Society Meetings. Seattle, Washington.

Anderson, D. P dan A. K. Siwicki., 1994. Simplited Assay For Measuring Nonspescific Depense Mechanism In Fish. Rough Draft For Presentation at The Fish Healt Section / American Fisheries Society Meetings, Seatle Woshington. 239 pp.

Bacha, L. M, and W. J. Bacha. 2000. Color Atlas of Veterinary Histology. Ed ke-2. Newyork (US): Lippincot Williams \& Wilkins.

Boyd, C. E. 1990. Water Quality in Pond Aquaculture. Birmingham Publishing Co. Alabama.

Cheng, W., C. Liu, S. Yeh, J. Chen. 2004. The Immune Stimulatory Effect of Sodium Alginate on the White Shrimp Litopenaeus vannamei and its Resistance Against Vibrio alginolyticus. Fish \& Shellfish Immunology 17: 41-51

Cipriano, R.C. 2001.Aeromonas hydrophilaand Motile Aeromonand Septicemias of Fish. Disease Leaflet 68. Washingron DC. $20 \mathrm{hlm}$.

Effendi, H., 2003. Telaah Kualitas Air bagi Pengelolaan Sumberdaya dan Lingkungan Perairan. Departemen Sumberdaya Perairan, Fakultas Perikanan dan Ilmu Kelautan, Institut Pertanian Bogor. Bogor.

Galeotti, M. 1998. Some Aspects of the Application of Immunostimulants and A Critical Review of Methods for Their Evaluation. J. Appl. Ichthyol. 14: 189-199.

Gallaugher PH, H Thorarensen and AP Ferrel. 1995. Hematocrit in Oxygen Transport and Swimming in Rainbow Trout Oncorhynchus mykiss. Respiration Physiology. 102: 279-292.

Harikrishnan, R., M. Kim, J. Kim, Y. Han, I. Jang, C. Balasundaram. 2011. Immunomodulatory Effect of Sodium Alginate Enriched Diet in Kelp Grouper Epinephelus brneus against Streptococcus iniae. Fish \& Shellfish Immunology 30: 543:549

Irmawati. 2013. Respons Fisiologis, Biokimia, dan Molekuler Ikan Gurame yang diberi Hormon Pertumbuhan Rekombinan. Disertasi. Bogor. Institut Pertanian Bogor.

Jasmanindar, Y. 2009. Penggunaan Ekstrak Gracilaria verrucosa Untuk Meningkatkan Sistem Ketahanan Udang Vaname Litopenaeus vannamei. Thesis. Sekolah Pasca Sarjana. IPB. Bogor

(Respon Imun Non-spesifik ............ Cahyono Purbomartono, Dini Siswani Mulia, Danang 
Khairuman dan Amri, K., 2003. Pembenihan dan Pembesaran Gurame Secara Intensif. PT Agromedia pustaka, Jakarta.

Kuswandi, Y. 2006. Pengaruh Pemberian Resin Lebah Terhadap Gambaran Darah Mas koki (Carassius auratus) yang Terinfeksi Bakteri Aeromonas hydrophila. Skripsi. Program Studi Budaya Perairan, Fakultas Perikanan dan Ilmu Kelautan, Institut Pertanian Bogor.

Marifatun, K. 2015. Pengaruh Pemberian Ekstrak Gracilaria verrucosa Terhadap Respons Imun Non Spesifik dan Aktivitas Aglutinasi Ikan Nila (Oreochromis niloticus). Skripsi. Fakultas Ilmu Pendidikan. UMP. Purwokerto

Marthen, DP. 2005. Gambaran Darah Ikan Nila Oreochromis sp. yang diberi Pakan Lemak Patin sebagai Sumber Lemak dalam Pakan. Skripsi. Fakultas Perikanan dan Ilmu Kelautan. Institut Pertanian Bogor.

Mathias Jr, Dodd Me, Walters K.B, Yoo S.K, Ranheim EA, Huttenlocher A. 2009. Characterization Of Zebrafish Larval Inflammatory Macrophages. Developmental and Comparative Immunology. Vol. 33. No. 11. P. 1212-1217.

Neumann N.F, Barreda D.R, Belosevic M. 2000a. Generation And Functional Analysis Of Distinct Macrophage Subpopulations From Goldfish (Carassius auratus L.) Kidney Leukocyte Cultures. Fish And Shellfish Immunology. Vol. 10. No. 1. P. 120.

Neumann N.F, Stafford J.L, Barreda D, Ainsworth A.J, Belosevic M. 2000b. Antimicrobial Mechanisms Of Fish Phagocytes And Their Role In Host Defense. Developmental And Comparative Immunology. Vol. 25. No. 8-9. P. 807-825.

Prajitno, A. 2005. Diktat Kuliah Parasit dan Penyakit Ikan. Fakultas Perikanan Universitas Brawijaya. Malang. 104 hal.

Prasetya, T. 2009. Pembuatan Natrium Alginat dari Rumput Laut Cokelat (Phaeophyceae) dengan Proses Ekstraksi. Skripsi. Departemen Teknik Kimia. Fakultas Teknik. Universitas Sumatera Utara. Medan

Puspita, N. 2010. Evektifitas Ekstrak Rumput Laut Gracilaria verrucosa Sebagai Imunostimulan Untuk Pencegahan Infeksi Bakteri Aeromonas hyrophila Pada Ikan Lele Dumbo Clarias sp. Skripsi.Departemen Budidaya Perairan Fakultas Perikanan Dan Ilmu Kelaitan. IPB. Bogor

Rawling MD, Merrifield DL, Snellgrove DL, Kuhlwein H, Adams A, dan Davies SJ. 2012. Haemato-immunological and growth response of mirror carp (Cyprinus carpio) fed a tropical earthworm meal in experimental diets. Fish \& Shellfish Immunology 32:1002-1007.

Ridlo, A dan R. Pramesti. 2009. Aplikasi ekstrak rumput laut sebagai agen imunostimulan sistem pertahanan non spesifik pada udang (Litopennaeus vannamei). Jurnal Ilmu Kelautan vol. 14(3): 133-137.

Rieger AM dan Barreda DR. 2011. Antimicrobial mechanisms of fish leukocytes. Developmental and Comparative Immunology 35:1238- 1245. doi:10.1016/j.dci.2011.03.009.

Taufik P. 1984. Faktor Kualitas Air dapat Mempengaruhi Timbulnya Suatu Penyakit pada Ikan. Majalah Pertanian No.3, tahun ke-31. Jakarta: Departemen Pertanian. Hlm 21.

Wedemeyer GA and WT Yasutake. 1977. Clinical Methods for the Assessment of the Effect Environtment Stress on the Fish Health. Technical Papers of the US Fish and Wildlife Service. US Depart of the Interior Fish and Wildlife Service. 89:1-17p.

(Respon Imun Non-spesifik ............ Cahyono Purbomartono, Dini Siswani Mulia, Danang 